29

30

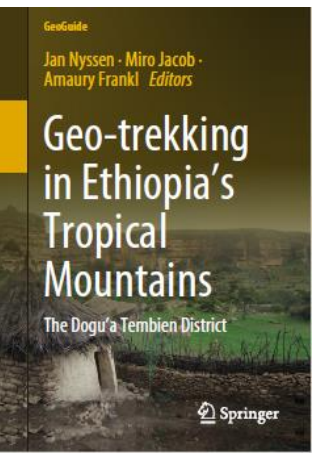

Aerts R. 2019. Forest and woodland vegetation in the highlands of Dogu'a Tembien. Pp. 233-250 in: Nyssen J., Jacobs M., Frankl A. (Eds.) Geo-trekking in Ethiopia's Tropical Mountains. The Dogu'a Tembien District. GeoGuide. Springer nature Switzerland AG. https://doi.org/10.1007/978-3-030$\underline{04955-3 \quad 15}$

Authors whose work is accepted for publication in a non-open access Springer book may deposit their author's accepted manuscript (AAM) in their institutional or funder repository, provided that the following conditions are observed. The author's accepted manuscript is the version of the book manuscript accepted for publication after peer review, but prior to copyediting and typesetting. The self-archived AAM should not include any changes made after the point of editorial acceptance. Any necessary amendments or corrections to article content should be made to the version of record (VoR) on the publisher platform.

To access the final edited and published work see https://doi.org/10.1007/978-3-030-04955-3

(C) 2019. This manuscript version is made available under the CC-BY-NC-ND 4.0 license http://creativecommons.org/licenses/by-nc-nd/4.0/

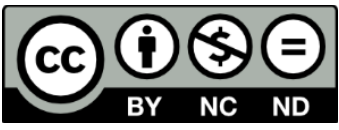




\section{Forest and woodland vegetation in the highlands of Dogu'a Tembien}

32 Raf Aerts, University of Leuven, Belgium

34 Much of the available land in Dogu'a Tembien is under cultivation or is used as grazing land.

35 Open woodland of small shrub and tree species has regenerated during the past decades in

36 exclosures (see Chapter 18), but semi-natural forest vegetation remains largely restricted to

37 small, isolated patches. These patches are most often church yards and other sacred sites. In this

38 chapter, the historical forest vegetation of the Ethiopian highlands and how this vegetation

39 changed are briefly described, an overview of the different Afromontane forest types of the

40 Ethiopian highlands is given and the present vegetation of church forests in the dry Afromontane

41 forest zone is described. Against this broad ecological background of the dry Afromontane

42 forests, the forest and woodland vegetation of Dogu'a Tembien is discussed.

\subsection{Historical forest vegetation, clearance and regrowth}

45 Pollen records from Ashenge and Hayk lakes indicate that the natural vegetation of the northern

46 Ethiopian highlands, before the large scale human transformation of the landscape, was

47 Afromontane Afrocarpus-Juniperus forest, with Afrocarpus falcatus (yellowwood, previously

48 known as Podocarpus falcatus), Juniperus procera (African cedar) and other high-elevation

49 species. This primary mixed forest was cleared and, presumably under the influence of heavy

50 livestock grazing, replaced by a secondary vegetation shrub and grassland at about 500 BCE,

51 with Dodonaea and Rumex as disturbance indicators in the pollen record. Interestingly, dry 
52 Afromontane Juniperus forest with secondary or intermediate species such as Olea europaea

53 ssp. cuspidata (African wild olive) and Celtis africana (white stinkwood) expanded in the

54 northern highlands from 1400 to $1700 \mathrm{CE}$, potentially a result of accelerated secondary

55 succession following increased rainfall, reduced human impact, or a combination of both.

56 Clearing of these forests, excessive harvesting of high-quality timber, increased livestock grazing

57 and subsequent land degradation throughout the past three centuries have led to the present

58 dominance of drought-resistant and often thorny savanna tree and shrub species in the

59 uncultivated parts of the landscape. In Dogu'a Tembien, these species include Acacia etbaica, A.

60 abyssinica, Euclea racemosa, Senna (Cassia) singueana, Dodonaea angustifolia and

61 Dichrostachys cinerea. Despite the high demand for wood and grazing land, isolated patches of

62 dry Afromontane forest vegetation have persisted throughout the northern highlands for centuries

63 as a result of the traditional protection of vegetation near churches and other sacred sites (Photo

64 16.1). A study that compared historical aerial photographs to present-day satellite imagery of 37

65 of such church forests in the hills east of Lake Tana demonstrated that, at least over the past 80

66 years, church forests have hardly changed in size. Conversely, trees and natural vegetation in the

67 landscape surrounding the church forest disappeared. In the forest, species composition,

68 structure and tree population dynamics may have been affected by these changes in the

69 surrounding matrix and by forest management, but at least the shape and thus the extent of the

70 church forests remained largely the same. A comparison between an oblique aerial photograph

71 of 1936 and a satellite image of 2016 demonstrates that the extent of the eastern part of Chege

72 church forest, a large forest just west of Dogu'a Tembien, also has not changed since at least

731936 (Photo 16.2) 


\subsection{Afromontane forest and woodland vegetation}

76 A number of different types of Afromontane forest vegetation occur in the Ethiopian highlands.

77 According to the most recent classification of vegetation in Ethiopia by Friis et al., the potential

78 natural vegetation of the Ethiopian highlands between 1800 and $3000 \mathrm{~m}$ altitude is "dry

79 evergreen montane forest and grassland complex" in areas with rainfall below $1700 \mathrm{~mm}$ per year

80 (northern and central highlands), and "moist evergreen Afromontane forest" in areas where

81 rainfall exceeds $1700 \mathrm{~mm}$ per year (southern and southwestern highlands; this forest type does

82 not occur in Dogu'a Tembien).

83 The dry evergreen montane forest is not one well defined forest type, but a collective designation

84 for a landscape mosaic of different dry forest and woodland types varying from grasslands with

85 shrubs and trees to closed-canopy forest. It is nevertheless possible to define several dry

86 evergreen montane forest subtypes based on differences in the dominance of the indigenous

87 coniferous species A. falcatus and J. procera and in the relative abundances of grass, shrubs or

88 broadleaved trees present in the forest.

89 A first subtype of the dry evergreen montane forest is the "undifferentiated Afromontane forest",

90 a forest type that is presumably similar to the historical Afrocarpus-Juniperus forest mixed with

91 broadleaved species such as Croton macrostachyus, Ficus species and O. europaea. The two

92 indigenous conifers can be equally important or one of the two species can be dominant in the

93 undifferentiated Afromontane forest. A second, drier, subtype of the dry evergreen montane

94 forest is the "dry single-species dominant Afromontane forest of the Ethiopian highlands" with

95 Juniperus the dominant species in the upper storey and Olea as well as other species in the

96 middle and under storey. 
97 In Dogu'a Tembien, and in the northern highlands in general, the dry evergreen montane forest

98 transitions into Combretum-Terminalia woodland and wooded grassland below $1800 \mathrm{~m}$, with

99 (sometimes very locally) very interesting species such as Adansonia digitata (baobab, e.g. near 100 Agbe) and Boswellia papyrifera (frankincense tree, in the Giba gorge, see Chapter 22). Above $1013000 \mathrm{~m}$, the dry evergreen forest is flanked by the ericaceous belt (3000-3200 m) with Erica 102 arborea (tree heath); this belt gradually changes into the afro-alpine belt on higher mountains (> $1033200 \mathrm{~m}$ ). The plateau of Dogu'a Tembien peaks at $2845 \mathrm{~m}$ and the area is therefore too low to 104 sustain ericaceous or afro-alpine vegetation.

\subsection{Church forests as islands of forest biodiversity}

107 A study of satellite images of 394 church forests within the dry evergreen montane forest zone of 108 neighbouring church forest (Photo 16.3). There is approximately only one church forest per 10 $\mathrm{km}^{2}$. In the northern highlands, church forests tend to have a more complex shape and are

112 located on steeper slopes than in the southwest, where church forests are often perfectly circular, 113 with a sharp boundary and with the church in the center of the forest. The sizes of 38 church 114 forests in Dogu'a Tembien identified on satellite images ranged between 0.36 and 63 ha, with a total surface area of 330 ha. By size, church forests were distributed over 5 size classes: $\leq 2$ ha $116 \quad\left(\mathrm{~N}=11\right.$; mean 1.03 ha; SD 0.51 ha; $\sum 11.32$ ha); $2-5$ ha $\left(\mathrm{N}=10\right.$; mean 3.54 ha; SD 0.86 ha; $\sum$ 11735.40 ha); 5-10 ha ( $=9$; mean 5.96 ha; SD 1.46 ha; $\sum 53.65$ ha $) ; 10-30$ ha $(\mathrm{N}=5$; mean 16.90 118 ha; SD 5.32 ha; $\sum 84.52$ ha); and $>30$ ha (Waseya, 48.29 ha; May Mirara, 63.06 ha; and a forest 
119 without a church located in between those two forests, $34.11 \mathrm{ha}$ ). The church forests of Dogu'a 120 Tembien usually have a very diffuse edge and many of the forests in the larger size classes are 121 rather open woodlands that transition into shrubland.

122 A ground survey of 78 church forests within the dry evergreen montane forest zone of the

123 Ethiopian highlands showed that O. europaea (present in $71 \%$ of the surveyed forests),

124 Juniperus procera (67\%) and Croton macrostachyus (54\%) (and not Afrocarpus, 19.2\%) are the 125 most prevalent tree species in church forests. In the understorey, Calpurnia aurea and Carissa 126 spinarum (both 74\%) are the most common shrub species. Also in and around Dogu'a Tembien 127 O. europaea is indeed the keystone tree species of most church forests (Photo 16.4). Across the 128 surveyed forests, a total of 148 indigenous tree, shrub and liana species were recorded, but, on 129 average, there were only 25 woody species recorded per forest patch. The number of species per 130 forest patch increased from northeast to southwest with increasing mean annual precipitation; 131 this means that the church forests in Dogu'a Tembien belong to the drier and relatively species132 poor church forests of the Ethiopian highlands. Common secondary and intermediate species of 133 the church forests of Dogu'a Tembien include Acacia etbaica, A. abyssinica, A. seyal, 134 Acokanthera schimperi, Aloe macrocarpa, Celtis africana, Calpurnia aurea, Combretum 135 collinum, Cordia africana, Cassia singueana, Euphorbia abyssinica, Euclea racemosa, 136 Faidherbia albida, Ficus vasta, Maytenus senegalensis and Rhus natalensis. Exotic timber (e.g. 137 Eucalyptus spp., Cupressus lusitanica, Grevillea robusta) and fruit tree species (e.g. Psidium 138 guajava, common guava) are often planted in or near the church forests.

139 The vegetation of the 78 ground-surveyed church forests (across the dry evergreen montane 140 forest zone) could be classified into four plant communities. Two communities belonged to the 141 dry single-species-dominant Afromontane forest and the other two to the undifferentiated 
142 Afromontane forest. The plant communities of the undifferentiated Afromontane forest type

143 were predominantly found in the central highlands and were mixed conifer forest with Juniperus

144 or with Juniperus and Afrocarpus as dominant species, both mixed with broadleaved species.

145 The plant communities of the dry single-species-dominant Afromontane forest type were

146 degraded Olea-Acacia woodland and typical dry Afromontane forest dominated by Juniperus

147 with Olea and other secondary species.

148 The church forests of Dogu'a Tembien are predominantly remnants of Olea-Acacia woodland 149 and Juniperus-Olea forest. The nearest remnant population of Afrocarpus trees is found in the 150 National Forest Priority Area Hugumburda, a relatively well-conserved dry Afromontane forest 151 located in a secluded, relatively moist valley next to the parallel rift of Lake Ashenge.

152 The Olea-Acacia woodland is an open woodland with relatively few tree species and a low, 153 single-storied, discontinuous canopyIn the rainy season, grasses and herbaceous vegetation, 154 including Bidens prestinaria, emerge under this open canopy (Photo 16.5). Natural tree 155 regeneration is very poor or entirely lacking, because very few seedlings are able to survive the 156 dry season in these open woodlands. This has resulted in skewed tree diameter distributions and 157 threatens these church forests in the long term. Near the lower ranges of the dry evergreen 158 montane forest zone, the Olea-Acacia woodland may contain elements of the Combretum159 Terminalia woodland and wooded grassland, such as Combretum collinum. This forest type 160 attracts biota from habitats of lower altitudes, including birds from the Sahel and Northern Africa 161 (Chapter 20).

162 The Juniperus-Olea forest usually has a two-storied canopy, with Olea trees underneath a tall 163 overstorey of Juniperus trees,but in Dogu'a Tembien Juniperus is very rare and small or entirely 
164 lacking and because of internal degradation this canopy is very often open and patchy.. This

165 phase of the dry evergreen montane forest may be defined as dry Afromontane forest dominated

166 by Olea (Photo 16.6). In more or less closed canopy Juniperus-Olea forests, especially in the

167 higher ranges, epiphytic lichens and orchids can form an important component of the forest

168 ecosystem. Beard lichens and orchids intercept water from clouds and contribute to the local

169 hydrological cycle. In Dogu'a Tembien, epiphytic orchids and lichens have become very rare.

170 Even the once widespread orchid Polystachya bennettiana with its light greenish yellow or

171 cream flowers has disappeared from many church forests, presumably following unfavourable

172 changes in the forest microclimate. Even in the National Forest Priority Area Dessa'a, a large

173 but degraded dry Afromontane forest dominated by stunted Juniperus with Olea on the western

174 Great Rift escarpment, lichens and orchids are becoming increasingly rare. In most church

175 forests, however, patches with nearly complete crown closure and dense undergrowth remain

176 (Photo 16.7), for instance where woody climbers such as Pterolobium stellatum have overgrown

177 the canopy, or near large fig trees (e.g. Ficus vasta) (Photo 16.8). These pockets of dense

178 vegetation act as surrogate forest 'core' area and are important for understorey bird species

179 (Chapter 20), as well as for large mammals that hide in these almost impenetrable thickets during

180 the day - most notably the spotted hyena (Plate XX). Other mammals that have been observed

181 in or near the church forests and other more or less woody habitats of Dogu'a Tembien include

182 hamadryas (near Waseya forest), olive baboon, grivet (also known as African green or Savannah

183 monkey; the most common primate in the area), klipspringer, black-backed jackal, honey badger,

184 African civet, small-spotted genet (often under church roofs and in large trees, including

185 Euphorbia), large grey and white-tailed mongoose, African wild cat, caracal, (occasionally) 
186 leopard, rock hyrax (on steep cliffs and in large trees), cape hare, unstriped ground squirrel and 187 crested porcupine (Plate XX).

188 A number of relatively large church forests has been conserved along the Tsaliet River to the west of Tinsehe waterfall - Haragua ( 13 ha; Photo 16.9) and Abiy Dur ('Large Forest') in

190 Waseya ( 48 ha; Photo 16.10) - and in the Tanqwa valley - May Mirara ( 63 ha; Photo 16.11), 191 a forest without church, and Chege ( 75 ha; Photo 16.6) (Chege lies just west of the 192 administrative boundary of Dogu'a Tembien). These forests cover steep west-facing slopes and 193 extend from the edge of the plateau towards the lower limit of the dry evergreen montane forest 194 and grassland zone. A favorable rainfall regime during the main Kremt rainy season (Figure 3.3) 195 may explain why these forests are larger and less degraded that other forests in Dogu'a Tembien. 196 These forests are the most intact dry evergreen montane forests in Dogu'a Tembien. Relic 197 populations of Juniperus are conserved in the church forests of May Mirara and especially 198 Waseya. These forests also contain Afromontane highland biome bird species that were not 199 recorded in the smaller, more degraded forests of Dogu'a Tembien, such as white-cheeked turaco 200 or Abyssinian oriole (Chapter 20). Satellite imagery provides evidence that these large forests 201 have not changed in size since at least 1984.

202 Church forests in northern Ethiopia have been quite literally islands of forest biodiversity for 203 decades and are likely to remain isolated patches for many more years because of the slow pace 204 of natural regeneration of forest microclimate and structure in exclosures (Chapter 18). In 205 Dogu'a Tembien, church forests and some large, well-developed exclosures are the most 206 important forests and woodlands of the area. These forests have an important conservation value 207 for plants, birds and mammals and are vital seed sources of indigenous tree species for natural 208 and assisted regeneration in exclosures and for the production of tree seedlings in nurseries. . In 
209

210

211

212

213

214

215

216

217

218

219

220

221

222

223

224

225

226

227

228

229

Chapter 20, we suggest a few sites that are interesting for birdwatching but we do stress that it is important to seek prior informed consent to visit church forests and other sacred sites including woodlots around "holy waters".

\section{References}

Aerts R, Van Overtveld K, Haile M, Hermy M, Deckers J, Muys B (2006) Species composition and diversity of small Afromontane forest fragments in northern Ethiopia. Plant Ecology $187: 127-142$

Aerts R, Van Overtveld K, November E, Wassie A, Abiyu A, Demissew S, Daye DD, Giday K, Haile M, TewoldeBerhan S, Teketay D, Teklehaimanot Z, Binggeli P, Deckers J, Friis I, Gratzer G, Hermy M, Heyn M, Honnay O, Paris M, Sterck FJ, Muys B, Bongers F, Healey JR (2016) Conservation of the Ethiopian church forests: threats, opportunities and implications for their management. Science of the Total Environment 551-552:404-414

Aynekulu E, Aerts R, Moonen P, Denich M, Gebrehiwot K, Vagen TG, Mekuria W, Boehmer HJ (2012) Altitudinal variation and conservation priorities of vegetation along the Great Rift Valley escarpment, northern Ethiopia. Biodiversity and Conservation 21:2691-2707

Aynekulu E, Aerts R, Denich M, Negussie A, Friis I, Demissew S, Boehmer HJ (2016) Plant diversity and regeneration in a disturbed isolated dry Afromontane forest in northern Ethiopia.

Folia Geobotanica 51:115-127

Darbyshire I, Lamb H, Umer M (2003) Forest clearance and regrowth in Northern Ethiopia during the last 3000 years. The Holocene 13:537-546 
230 Friis I, Demissew S, van Breugel P (2010) Atlas of the potential vegetation of Ethiopia. Biol.

231 Skr. Dan. Vid. Selsk. 58:1-307

232 Klepeis P, Orlowska IA, Kent EF, Cardelús CL, Scull P, Eshete AW, Woods C (2016) Ethiopian

233 church forests: a hybrid model of protection. Human Ecology 44:715-730

234 Scull P, Cardelús CL, Klepeis P, Woods CL, Frankl A, Nyssen J (2017) The resilience of

235 Ethiopian church forests: interpreting aerial photographs, 1938-2015. Land Degradation and

236 Development 28: 450-458

237 Woods CL, Cardelús CL, Scull P, Wassie A, Baez M, Klepeis P (2017) Stone walls and sacred

238 forest conservation in Ethiopia. Biodiversity and Conservation 26: 209-221 